\title{
Shaping your Identity as a Speaker of English: The Struggles of a Beginner Language Learner
}

\section{Construir su identidad como hablante de inglés: los retos de un principiante}

Janeth María Ortiz Medina'

Citation/ Para citar este Artículo: Ortiz, J. (2017). Shaping your Identity as a Speaker of English: The Struggles of a Beginner Language Learner. Colomb. appl. linguist.j., 19(2), pp. 250-262.

Received: 01-Apr-2016 / Accepted: 23-May-2017

DOI: http://dx.doi.org/10.14483/22487085.10238

\begin{abstract}
In Colombia, political and educational campaigns have promoted English as the language of success and as a fundamental requirement to comply with the demands of a globalized world; nevertheless, little attention has been paid to the individual experiences of Colombians as they learn this language or to what happens to their identities during this process. This paper reports on a study that explored how three young adult learners of English constructed their identities as speakers of English through their positioning in oral tasks in an English class. It focuses on the story of one of the participants: a beginner female English learner. Data collection methods included class video and audio-recordings, interviews, and diaries kept by the participants. Findings indicated that learners' positioning in spoken interactions not only directly affected their use of English, but also led them to non-linear transformations of their identities as speakers of English. These results pinpoint the need to gain awareness of the centrality of students' identities in both their learning process and in language teaching practices and the need to observe how positioning operates in the language classroom.
\end{abstract}

Keywords: identity construction, knowledge-power relations, language learning, positioning

\section{Resumen}

En nuestro país, las campañas políticas y educativas han promovido el inglés como la lengua del éxito y como requisito fundamental para cumplir con las exigencias de un mundo globalizado; sin embargo, poca atención se ha puesto a las experiencias particulares de los colombianos cuando aprenden esta lengua o a lo que pasa con sus identidades durante este proceso. Este artículo está basado en un estudio que exploró cómo tres adultos jóvenes, aprendices de inglés, construían sus identidades como hablantes de esa lengua mediante su posicionamiento en actividades orales de clase. El artículo se enfoca en la historia de una de las participantes del estudio: una aprendiz de inglés principiante. Los métodos de recolección de datos incluyeron grabaciones de video y audio de las clases, entrevistas y diarios escritos por los participantes. Los hallazgos del estudio mostraron que el posicionamiento de los aprendices en las interacciones orales no solo tuvo un impacto en su uso del inglés, sino que también los llevó a transformaciones no lineales de sus identidades como hablantes de esa lengua. Estos resultados señalan la necesidad de crear conciencia sobre el papel central de las identidades de los estudiantes tanto en su proceso de aprendizaje

1 Universidad de Antioquía, Medellín, Colombia. jmaria.ortiz@udea.edu.co 
como en las prácticas de enseñanza de lengua; así como la necesidad de observar cómo operan las dinámicas de posicionamiento en la clase de lengua.

Palabras clave: aprendizaje de lenguas, construcción de identidad, posicionamiento, relaciones conocimiento-poder

\section{Introduction}

In a world where English has been marketed by the neoliberal ideology as the means for nations to achieve economic success (Macedo, Dendrinos, $\mathcal{E}$ Gounari, 2003), understanding identity construction processes in English language learners has become paramount. English not only influences individuals' views of who they are, who they want to become, and their desires to belong to imagined communities, but also shapes the identities of whole nations and defines new relations among them (Pavlenko $\varepsilon$ Norton, 2007). In the case of Colombia, following a view of English as a "super" language that every citizen needs to learn in order to meet the demands of today's world (Macedo et al., 2003), countless efforts have been made by our government to promote the learning of this language, as described in the National Program of Bilingualism (Programa Nacional de Bilingüismo, MEN). Consequently, speaking English has become highly valued since it is viewed as the key to access more opportunities and to achieve visibility in the world's economic market (Mejía, 2006). Nevertheless, the individual experiences of Colombian English learners or what may happen to their identities as they learn English to comply with the demands of a globalized world have not been considered by these political campaigns.

At an international level, most studies regarding identity in language learning have revolved around the lives of individuals who have settled in English speaking countries and undergo a series of struggles that involve the negotiation and reshaping of their identities (Block, 2007). Some of these studies have focused on the relation among immigrant learners, their language learning context, and issues of power and identity (Morita, 2004; Norton, 2000); others analyze the relationship between immigrant leaners' experiences, language ideologies, and discourses of immigration and belonging (Warriner, 2007). Equally, there are also some studies on the development of identities of young Latino (a) students in mainstream and bilingual classrooms (Hawkins, 2005; Jiménez, 2000; Monzó E Rueda, 2009; Rymes E Pash, 2001).

Although few research studies addressing processes of identity construction in English learners have been conducted in Colombia, there has been a growing interest in this regard in the last few years. First, some researchers have studied processes of construction of gender identities in the language classroom. Castañeda (2008), for instance, explored how preschool learners' identities are affected by gendered discourses. Rojas (2012) described how, through their feminities, adult EFL language learners construct their identities and power relations in their class interactions at the university level. Rondón (2012) analyzed how EFL LGBT university students drew on different discourses to resist, adapt, and negotiate the heteronormative classroom discourse. Second, other researchers have focused on the study of learners' identities through the observation of classroom interaction from different perspectives. Gómez (2012) analyzed how university students construct different identities as language learners through their interaction with the English teacher. Montenegro (2012) explored EFL learners' positioning in group work and how their positioning determines different structures of participation in collaborative tasks; and Escobar and Gómez (2010) described how individuals from ethnic minorities reshape their identities through language and language learning.

The above-mentioned studies conducted in our context show how identity construction processes are determined by unequal and dynamic power relations, confrontation among opposing discourses, and negotiation of subject positions. Interestingly, these studies have contributed to a better understanding of how EFL learners' positioning in the classroom is related to their personal life histories, their social realities, and some of their learning practices. Nonetheless, these studies do not directly address the impact that learner's positioning in specific 
class activities has on their use of English and on the shaping of their identities as speakers of this language, issues that will be dealt with in this paper.

\section{Theoretical Framework}

\section{Identity and Subject Positions}

Poststructuralist perspectives that see identity as multiple, dynamic, fragmented, and contradictory (Canagarajah, 2004; McKinney \& Norton, 2008; Norton Peirce, 1995) guided this study. According to these theories, the self is constructed through discourse and language and has multiple subjectivities with unequal status and power. As a result, subjects need to negotiate conflicting identities and subject positions and, therefore, their selves are continuously shaped according to real, discursive contexts (Canagarajah, 2004).

In tune with this view of identity as constructed through social interaction and therefore as "dynamic, contextual, and relational" (Andreouli, 2010, p. 14.1), this study identified with Norton Peirce's (1995) view of identity as the way "people understand their relationship to the world, how that relationship is constructed across time and space, and how people understand their possibilities for the future" (p. 410). Moreover, identity construction processes take place through the adoption of specific positions or subject positions in a given context (Andreouli, 2010; Hall, 2000; Holland E Leander, 2004). Identities are "points of temporary attachments to subject positions which discursive practices construct" (Hall, 2000, p. 17).

Drawing on these views of identity, and in order to explore how learners constructed their identities as speakers of English, I observed the ways they positioned themselves and others in the language classroom; therefore, I resorted to Harré and Moghaddam's (2003) positioning theory. To these authors, a position is a transitory set of rights and duties that allow or forbid individuals to do certain socially meaningful acts. In any social group, there is a system of positions "which people can adopt, strive to locate themselves in, be pushed into, be displaced from or be refused access to, recess themselves from and so on, in a highly mobile and dynamic way" (pp. 5-6). According to Harré and Moghaddam (2003), positions actually limit the range of actions a person can do in a specific time and context. In this view, since individuals position themselves in relation to others, positioning is likely to be controlled by those who benefit from it. However, their theory also contemplates the possibility to refuse being positioned in a certain way and to be repositioned or reposition oneself (p. 7).

\section{Learning and Language in the Construction of Identity}

Wenger's (1998) social theory of learning as social participation also informed the perspectives of this study. According to Wenger (1998), participation "refers to being an active participant in the practices of social communities and constructing identities in relation to these communities. [...] Such participation changes not only what we do, but also who we are and how we interpret what we do" (p. 4). Learning is then participating in new activities and assuming different positions in the communities in which we belong (Wortham, 2004).

This study is also informed by socioconstructivist views of language, understood as "constitutive of and constituted by a language learner's social identity" (Norton, 1995, p. 13) and as shaped by the "social, cultural and political contexts" in which language occurs (WatsonGegeo, 2004, p. 334). Language is one of the most important social practices through which we come to "experience ourselves as subjects" (Donald, as cited in Macedo et al., 2003, p. 26); it is through language that learners negotiate their selves and are accepted or rejected in specific "powerful social networks" (Heller, as cited in Norton, 1995, p. 13).

\section{Subject Positions in the Language Classroom}

The construction of identities and, particularly, the ways in which English language learners position themselves and others is determined by how they interact in the power networks of the classroom. The concept of power that I would like to adopt here, however, is not tied to the binary 
relation between oppressed-oppressor; it rather follows the Foucauldian concept of power that circulates, that "is everywhere," and "comes from everywhere" (Foucault, 1998, p. 63). Within the Foucauldian view, power-knowledge relations are created by discourse and are used to create "truths" about the world. To Foucault, discourse can be seen as a system of representation, as "a group of statements which provide a language for talking about -a way of representing the knowledge abouta particular topic, at a specific historical moment [...] Discourse is about the production of knowledge through language" (Hall, 2001, p. 72). Furthermore, to Foucault the "effects of power" are related to "knowledge, competence, and qualification" and therefore opposing power means going against "the privileges of knowledge" (Foucault, 1982, p. 781).

In conclusion, the present study departed from the premise that learners' identities are transformed as they learn English through their participation in the power networks of the social community that is the classroom. Consequently, observing how learners construct their identities as speakers of English in the classroom posits the need to observe how they interact in that system of power relations through the adoption or rejection of specific positions and the different discourses they draw on. Using a poststructuralist lens, learners' identities-manifested through the adoption of specific subject positions in discoursewere seen in this study as co-constructed, shifting, temporary, and conflicting; and power relations, as socially-constructed and dynamic.

\section{Methodology}

This exploratory case study was conducted at a private language and cultural institute in Medellin, Colombia. The institution offers an English program for adults consisting of twenty-one courses. I selected three participants from the basic level of the program resorting to criterion sampling-the study of cases "that meet some predetermined criterion of importance" (Patton, 1990, p. 176). My choice was based on two reasons: first, English teachers in this institution tended to expect learners to start "speaking English" from the very first course. Second, I wanted to have students with different levels of participation in the in-class oral tasks. However, because of the space limit here, I will only present the story of one of the participants, the quietest one.

I decided to observe students interacting in oral tasks rather than in other class activities considering several key aspects of positioning theory, namely that "language exists only as concrete occasions of language in use" (Harré, as cited in Davies E Harré, 1990, p. 261), positioning is "a largely conversational phenomenon," and that conversation is a form of "social interaction" (Davies \& Harré, 1990). Accordingly, it is through conversation where positions are negotiated and subjectivities are constructed through discursive practices (Davies \& Harré, 1990). Therefore, I observed activities in which students could discuss different topics and that allowed me to observe their interactions as they spoke in English. During the study, learners were enrolled in two basic courses each lasting one month and had a two-hour lesson every day. As their teacher, I could get to know students better and design oral tasks that provided many opportunities to interact in conversation.

\section{Data Collection and Analysis}

For the purpose of this in-depth account, I collected data from different sources that included class video or audio-recordings, interviews, and diaries that the participants kept. The process of data collection lasted two months.

Interviews. The study included two structured interviews with each participant. The first was intended to provide data on the way learners initially described their identities as speakers of English, and included the following topics: a) students' life histories; b) discourses about English that students appropriated; and c) perception of their own competence in English. The second interview was implemented at the end of the study; it intended to go deeper into different aspects of their observed interaction and participation in class oral tasks such as: self-assessment of their performance in specific tasks; aspects that benefited or hindered their use of English in those tasks; feelings when interacting with different classmates; and their perceptions 
about changes or progress in their competence as speakers of English.

Class video and audio recordings. Most classes were videotaped or audio-recorded. I followed the steps suggested by Richards (2003) to analyze oral interaction. First, providing a general description of the context of the conversation and its participants; second, identifying salient features; third, focusing on structural elements (e.g., intonation, interruptions, silences); and fourth, developing a description of what happened during the interaction.

Participants' diaries. Participants wrote entries in their diaries twice a week describing the context of specific oral tasks (e.g., what the task was about, who they worked with, what they did or did not do during the task), and then reflected on their feelings, impressions, and assessment of their performance during the task. Diaries allowed me to triangulate information with data from the first interview and class recordings, to clarify or confirm specific interpretations of class interactions, and to raise more questions for other diary entries or for the second interview.

In order to analyze the data gathered, I used inductive analysis. This technique encompasses the analysis of diverse types of data, intends to identify recurring themes, and includes stages like coding, initial analysis, and crosschecking (Kamberelis $\varepsilon$ Dimitriadis, 2005). I read and analyzed the information from the interviews, diaries, and video recordings multiple times in order to establish different categories according to the general patterns found and to define different codes for them. The analysis was also enriched by the triangulation of data, since participants' views and reflections on the diaries, for instance, could also be contrasted with data provided in the interviews and class recordings.

\section{Results}

\section{Initial Identities as Speakers of English}

At the beginning of the study, the three participants described different aspects of their identities as speakers of English. Data analysis showed that their identities were highly influenced by their previous experiences in learning this language, dominant ideologies about English reflected in their discourses, that is, their representations of this language, some of their personality traits, and the way they felt when interacting with others. A very dynamic interaction among these elements led learners to shape their own identities as speakers of English with a specific level of competence and clear dreams and plans in their personal, academic, and professional life. As mentioned earlier, due to space limitations, I will share the story of one of the participants. The following is Vanessa's initial view of her own identity as a speaker of English.

Vanessa is a 19-year-old girl devoted to her studies of dental health. To her, English is a very important language that is everywhere; it is a "necessary evil," as she literally described it. Although she did not like English, her main motivation to study this language was her plan to pursue a career as a police officer, and English is an important component of education in that field (Interview 1, April 23, 2013). Regarding the perception of her own competence as a speaker of English, Vanessa felt as a true beginner since she had not taken seriously the chance to learn English in high school. Consequently, she thought that learning English had become increasingly difficult for her.

The truth is that it's become very hard [to learn English] for me, including basic things; I can't imagine how it will be when I get to an advanced level. I mean, when it comes to express my ideas, I get stuck; I understand, but I get stuck. I can't find the words to express what I mean. (Interview 1, April 23, 2013; original in Spanish, author's translation)

In addition, Vanessa observed that she needed to produce more complete sentences, increase her vocabulary repertoire, and improve her ability to understand spoken English. Moreover, she explained that the main reason why she found it hard to interact in English was her shyness and probably others' reactions to her mistakes:

I think the main reason [why it's difficult for me to speak in English] is that I have always been 
shy. I mean, in my field, dental health, I do better, but in this field [English] I do not know. If I say something wrong, [I think] they will make fun of me; it is because of those things that I do not understand. (Interview 1, April 23, 2013; original in Spanish; author's translation)

In brief, Vanessa's previous experience in learning English, some personal characteristics, her feelings, and her perceptions of others when interacting in English led her to describe herself initially as a speaker of this language who still had many difficulties in communicating, in other words, as a deficient speaker. Yet, English was an essential part of her expectations and dreams about the future, and therefore she was still willing to continue her journey to learn this language.

\section{Positioning in Oral Communicative Tasks and Use of English}

Data analysis indicated that the three participants of this study re-constructed and co-constructed their identities as speakers of English through the adoption of different subject positions during their interactions with classmates in oral tasks, and their positioning directly affected their use of English in those situations. During the course of this study, Vanessa's identity as a speaker of English went through different changes as she adopted different positions during class oral tasks: as less, equally, and more competent in relation to her classmates.

Positioning as a less competent speaker of English. Vanessa tended to refrain from expressing her ideas in English during tasks in which she had to speak to one or more peers that she perceived as more competent than her. For example, in one of the oral tasks, students were talking in pairs about activities they had done the previous weekend. The aim of the task was to find out what their classmate had done by improvising and trying to keep the conversation going. This time, Vanessa worked with another female student. The following is an excerpt from this interaction:

Student (J): Did you have a good week? Vanesa (V): Week es fin de semana? (Does week mean weekend?)

\author{
J: No, semana (No, week) \\ V: Eh, espere yo saco.... (Hold on, let me get...) \\ [She remains silent] \\ $\mathrm{J}$ : Did you have a good week? \\ $\mathrm{V}$ : I go to the movies with my friends \\ $\mathrm{J}$ : What movie did you see? \\ $\mathrm{V}$ : I see the movie $X X X X$ \\ $\mathrm{J}$ : What movie theater did you go? \\ V: Carrefour de la 65 \\ J: Oh, good for you! Pregúnteme usted a mí \\ (Now you ask me) \\ V: Eh... Did you went to the concert last week? \\ $\mathrm{J}$ : No, I didn't, I had a really bad week. \\ V: Ah, OK. Eh... ¿Qué le pregunto? ( $\mathrm{Hmm}$, what \\ can I ask you?) [She looks for information in her \\ book and both remain silent for some time]
}

(Video recording, May 22, 2013)

In her reflection of this activity in her diary, Vanessa wrote:

I worked with Juliana; we had to talk about any topic but in past tense. To be honest, I felt very insecure with her because I felt she knew more than I do; because of that, I figured the conversation was not going to be that spontaneous. [...]

It was like that during the whole conversation because I felt intimidated by her. I had the feeling that she might not want to work with me because of the situation, because of the silence; I did not know what to ask, I was like stuck. (Diary entry, May 22, 2013; original in Spanish; author's translation)

During the conversation with Juliana, Vanessa positioned herself as a less competent speaker; this seems to be the result of her assessment of Juliana's competence as "knowing more" and consequently feeling insecure. From this position, she performed different actions such as letting Juliana start the conversation, providing short answers, denying herself the right to ask questions or give opinions about what Juliana said. At the same time, she positioned Juliana as more competent, thus granting her the power to lead the conversation and the right to perform more actions (e.g., starting the conversation, asking questions, giving opinions, deciding who should ask the next question). 
In this task, Vanessa's self-positioning as less competent and therefore less powerful seemed to be due to her feeling threatened by the fact that Juliana "knew more." This made her think that Juliana would not want to work with her, as she asserted in her diary. Consequently, she decided to remain silent and could not ask questions. In behaving the way she did, Vanessa may have drawn on different discourses about language learners. For example, the tendency to believe that more competent learners do not benefit from interacting with less competent ones; or the belief that if you do not know something, you better remain quiet; a discourse in which those who know are the ones who have the right to speak.

In other oral tasks throughout the course in which Vanessa took this position as less competent, she tended to take similar actions to the ones described above. In trying to explain the reasons for her difficulties to speak in those situations, Vanessa mentioned, for example, her lack of vocabulary. However, a more determining factor seemed to be her loss of self-confidence when interacting with classmates she perceived as more competent.

Positioning as an equally competent speaker of English. According to the recordings analyzed in this study, in most oral tasks observed, Vanessa was able to position herself as an equally competent speaker in relation to her classmates. For instance, in her interaction during a small group conversation, Vanessa and two other students were talking about their memories from childhood and teenage years:

Vanessa (V): Yo te hago otra pregunta. (Let me ask you a question). Tell me about your first love.

Student 1 (S1): ¿Otra vez? (Again?)

V: No. Hábleme de su primer amor. Ahorita fue el primer beso. Pero... (No, tell me about your first love; I had asked you about the first kiss, but...) Student 2 (S2): Sí. Él dijo que... (Yes, he said that...)

V: Ah, yo no estaba. Ah bueno. (Oh, Ok. I wasn't here)

[They remain silent for a few seconds]

Student 3: Who is your best friend?
S1: No, I didn't I much friends because I yo estaba (I was...). Eramos seis (We were six). My best friends was Ediel, Calle, Zapata, Rendon, and Lia. ¿Cómo se dice molestar? (How do you say "molestar")?

$\mathrm{V}$ : Eh, disfrutar, enjoy.

S1. We enjoyed school much.

V: Ah! I like...

S2: ¿Cómo se dice dónde los conociste?

$\mathrm{V}$ : Where...

S1: Where did you...

$\mathrm{V}$ : Where did you meet? Meet es conocer

S2: Where did you meet?

S1: I meet in the school. I studied, I studied in

my classroom, and they was, they were in my

first platoon.

V: interesting!

(Class audiorecording, June 3, 2013)

Vanessa takes a very active role in this part of the conversation as she had most of the turns. Although she is not the one controlling the conversation, the actions she takes help a lot in having a successful conversation: She clarifies information in Spanish (as well as S1 and S2), answers some questions about vocabulary (as S1 did), gives short opinions about her classmate's answers, and also asks some questions (like S2 and S3). In performing similar actions to those of her peers, Vanessa is sharing power with them and together they accomplished the aim of the task.

In her diary entry about the previous task on June 5, Vanessa asserted that she felt more comfortable because her classmates made her feel confident in taking risks and she also emphasized on the importance of mutual collaboration:

I think my participation was good because I could express my ideas with the help of my classmates. I didn't know how to say some words, but I think my conversation was productive. Sometimes I also helped $X$ because he asked me things he didn't know and I could help him with what he needed. In general, everything [made me feel good] because we helped each other [...]. Their attitude was not negative; instead, they helped me and gave me ideas to continue with the 
conversation. (Diary entry, June 5, 2013; original in Spanish; author's translation)

When reflecting on her performance during the tasks in which she adopted or was granted a position as equally competent to her peers, Vanessa acknowledged her linguistic needs, but emphasized the things she could say and do effectively as a speaker of English during the conversations as shown in the following reflections from her journal.

\begin{abstract}
At the beginning, I felt nervous about the possibility to be asked questions and not knowing what to answer, but after starting, I felt very confident and I could express myself spontaneously. (Diary entry, May 8, 2013; original in Spanish; author's translation)

I felt at ease with my classmate and the conversation was nice; sometimes I had to use Spanish, though, because I did not know how to say an idea in English. [...] I knew how to express my ideas, not very well, but I kind of knew how to put the words together. (Diary entry, May 17, 2013; original in Spanish; author's translation) I could ask questions to my classmates to get more information and they understood and answered my questions. If I forgot a word, then I asked them or the teacher. (Diary entry, May 23, 2013; original in Spanish; researcher's translation)
\end{abstract}

Data analysis showed that by adopting a position as an equally-competent speaker in relation to her peers, Vanessa granted herself the right to perform more actions. In addition, data from the second interview and her reflections in the journal indicated that Vanessa tended to adopt that position when she felt comfortable with her interlocutors, when she interacted with classmates she usually shared with in class, and when she felt there was collaboration during the interaction.

Positioning as a more competent speaker of English. Data analysis also showed that there were a few occasions in which Vanessa adopted a position as a more competent speaker than some of her classmates. An example of this can be observed in the following conversation she held with one of her classmates, in which they were talking about activities they had done recently:

Student 1 (S1): Where did you meet people?

Vanessa: I met in a concert.

S1: Terminamos. (We're done)

V: No, siga, siga. (No, go on)

S1: Pregúnteme (Ask me a question)

$\mathrm{V}$ : Did you go to a concert last month?

S1: No, I didn't.

V: Eh, because? Ah no why, why?

S1: Because..... [She remains quiet]

V: Diga algo: no quise ir, no me gustó.... (Say

something: I didn't want to go, I didn't like it...)

S1: Because I don't like....

V: Bueno, eh... Did you...

S1: Qué es esto? (What's the meaning of this?)

$\mathrm{V}$ : Eso es encontrarse con alguien (That means meeting someone)

S1: Bueno, did you and your friends get together last Friday?

V: Eh... o sea, tú y tus amigos.... Yes, I did.

S1: Where did you last Friday?

V: Where did you get together last Friday? Usted

dijo otra cosa muy diferente! (You said something

very different...) Bueno, I get together in a bar.

(Audio recording, May 20, 2013)

In this conversation, both learners had a balanced number of turns. However, it was Vanessa who took the lead to keep the conversation going. Initially, when S1 wanted to finish the conversation, Vanessa insisted so she kept talking. Likewise, when S1 provided very short answers, Vanessa either asked a follow-up question or gave her some ideas to expand on her answers; she did this in Spanish. In addition, Vanessa also answered S1's question on vocabulary, and even corrected her when she made a mistake.

Through this conversation, Vanessa took a more powerful position in the interaction. She made this self-positioning evident when she asked S1 to continue talking at the beginning of the conversation. However, S1 also made this position available for Vanessa when she told her to ask her a question (agreeing to continue with the conversation). 
Through her positioning as a more competent speaker, Vanessa took the initiative to perform a wide range of actions during the conversation.

It is particularly interesting the way in which, from this more powerful position, Vanessa tried to convince S1 to perform some actions. At the beginning when she convinced S1 to continue the conversation, she said, "No, siga, siga"; then when asking $\mathrm{S} 1$ to expand on one of her answers, Vanessa said, "Diga algo: "no quise ir," "no me gustó"; at the end of the conversation, Vanessa also corrected what S1 had said by repeating her question and emphasizing her mistake: "Usted dijo otra cosa muy diferente!" The words Vanessa used in these instances seem to show a commanding attitude towards S1; such attitude can also be perceived in her intonation when listening to the recording. Vanessa did not soften her remarks; she seemed to be bothered by S1's responses and the way she interacted in the conversation. This uneasiness is expressed by Vanessa in her journal when reflecting about this task:

Teacher, in a few words, S1 really gets on my nerves. It's not that I know a lot or that I underestimate her; it's just that you have to translate everything for her so she understands and answers a question. She can't be bothered to try to understand the question by herself. I don't like her attitude. (Diary entry, May 24, 2013; original in Spanish; author's translation)

Considering the class recording and Vanessa's reflection in her journal about this task, one could say that not only Vanessa positioned herself as more competent than S1, but also positioned S1 as not willing to make an effort, a lazy student. Drawing from that discourse, she also positioned herself as the one who corrects, insists on doing things right, and even reprimands S1.

An interesting finding indicates that when Vanessa positioned herself as an equally or more competent speaker in relation to her peers, she claimed the right to perform a wider range of actions. For instance, she interacted more, dared to ask questions, confirmed her comprehension, and asked for help; she could also provide help to other classmates and, sometimes, she even led the conversation. As a result, these positions allowed Vanessa to strengthen her self-confidence and be more positive about her overall competence as a speaker of the language. This can be observed in several excerpts from the second interview conducted at the end of the study, in which Vanessa refers to her participation in different tasks.

Something I liked a lot about the last course was
the project presentation. I felt really good; I could
express my ideas and make myself understood.
When I was asked questions, I could answer
appropriately.
[In the project from this course] in general, I felt
good, I was nervous, but I felt good. There were
some words I forgot, and I had to check my
notes, but the rest was good.
In the previous course, I didn't do anything, I
didn't participate. At least now I dare to speak to
the person next to me; I interact more. (Interview
2, June 12, 2013; author's translation)

At the beginning of this study Vanessa described her difficulties in speaking in English during class activities as related not only to linguistic aspects but also to her shyness and her perception that classmates would not open up to her, thus selfportraying as a deficient speaker of the language. Towards the end of this study, she referred to her identity as a speaker of English in a more positive way: she described her progress in the language, acknowledged her needs, and the fact that she felt more accepted by her classmates. However, she also expressed still feeling nervous when interacting with classmates who knew more and with whom she did not feel comfortable during conversation. This can be observed in her reflections during the last interview:

When I started here, my mind was blank; everything was new to me, and I felt I didn't know anything. However, as you do it and you do some research on how things work, you start getting into it and getting the knack of it. [...] I used to feel like what should I do? Who can I talk to? And then I started to interact with $D$ 
and $\mathrm{N}$; D is kind of crazy and very spontaneous. And now I talk to all of them [...]; with them everything is more spontaneous, we are closer, so things have changed.

First of all, [what makes me feel better] is confidence. They make me feel more confident to take risks, even if I make mistakes or if I have to use Spanish. With other classmates, as I do not interact with them much, I feel they get along very well with each other, and they speak fluently, but with me the conversation gets stopped [...] Precisely because of that, because I feel refrained; I can't get my ideas across. (Interview 2, June 12, 2013; original in Spanish; author's translation)

In conclusion, through her positioning as an equally competent speaker in most oral tasks during this study, Vanessa seemed to have developed more confidence in her use of English. This allowed her to transform her initial identity as a deficient speaker into a more positive identity: a developing speaker of English, someone who is making progress little by little. Nevertheless, such transformation did not take place in a linear way, since throughout the process she adopted shifting and not necessarily progressive positions (from less to more competent, for example) according to the particular circumstances of negotiation of power-knowledge relations and discourses that she constructed with her peers during class conversations.

\section{Conclusion}

Research on the impact of learning English on English learners' identities has mainly been conducted in L2 contexts and focused on the struggles that newcomers have to face in order to be accepted in L2 communities. Thanks to these studies, we now know that new foreign students have to negotiate their identities in order to be accepted as valid members of an academic community (Morita, 2004). We have also realized that the experiences of new immigrant learners of English in the U.S. do not necessarily reflect the promises of success spread by dominant ideologies of language and language learning (Warriner, 2007). Moreover, we have discovered that the evolving identities of Latino(a) students in bilingual classrooms in the U.S. are influenced by their status as bilingual, bicultural, and biliterate and have an impact on their literacy development (Jiménez, 2000). Finally, we have realized that second language learners may sometimes use strategies to preserve a pretend identity, such as passing for a fluent speaker of English (Monzó \& Rueda, 2009) or passing as knowing (Rymes \& Pash, 2001) in order to fit in the school community. In short, these studies have helped us gain insights into the experiences of English learners as new comers to L2 settings and into how their identities are transformed as they face the challenges of those new contexts.

Similarly, several studies conducted in Colombia have made important contributions to the understanding on how English learners construct multiple learner identities in the language classroom through specific dynamics of positioning (Castañeda, 2008; Gómez, 2012; Montenegro, 2012; Rojas, 2012; Rondón, 2012). However, these studies have not addressed how EFL learners construct their identities as speakers of English through their interactions in the classroom or the impact that their positions have on their use of English, which was precisely what the present study intended to understand.

The analysis of Vanessa's story showed that her identity as a speaker of English went through a constant transformation as she adopted different subject positions that were mainly determined by her assessment of her own and her classmates' competence in English during specific oral tasks. Moreover, within a specific position Vanessa took a particular range of actions that included the decision to use English, Spanish, or Spanglish to express her ideas, ask for help, correct others, and even the decision to remain quiet. Vanessa's use or nonuse of English in oral tasks was the result of an intricate process of negotiation of subject positions in a network of power-knowledge relations within the English classroom for which she resorted to a variety of discourses. 
From a theoretical perspective, these findings may contribute to a better understanding of the multiple ways in which micro relations of power are constructed among FL learners in the English classroom-resulting in the adoption of subject positions that not only have an impact on learners' identities, but also on their use of English-and the ways such relations may reflect wider dynamics of power in society. In the positioning dynamics observed here through Vanessa's story, knowledge was a determining factor of how she handled power relations in specific interactions. For instance, those who were seen or positioned as more competent speakers of English (as knowing more) were granted by her more actions to perform, were given the right to speak, and in turn, they positioned their peers or led them to self-position as less competent (losing access to a range of actions). Such systems of positions determined by specific dynamics of knowledgepower relations are prevalent in every aspect of social life: in education, communications, medicine, and so forth, thus setting the rules to grant or deny the right to access benefits or privileges to individuals, communities, and countries. Consequently, gaining knowledge of the ways we participate in immediate power networks and becoming aware of how our positions affect ourselves and others can lead us to reflect not only on our roles, positions, and identities as learners, speakers, and teachers of English but also as members of the different communities we belong to. Such awareness might help us take actions to build more equitable relations in the power networks where we interact and impact wider dynamics of power.

From a pedagogical point of view, the findings from this study have made evident that the apparently simple ability to 'speak English' that language teachers inexorably demand from their learners is rather the result of a complex process of negotiation of power, subject positions, and even competence (or knowledge). This realization should necessarily lead to the interrogation of the effectiveness and relevance of teaching approaches and practices that intend to mechanically train learners to speak English, disregarding their selves and the conditions in which they are learning.
Furthermore, these findings emphasize the need for teachers to become keen observers of learners and the ways they relate to and interact with others in the classroom in order to question and take actions to improve our teaching practices from the knowledge gained through observation. Observing how learners position themselves and are positioned by others in class activities may help teachers reflect on which type of positions may offer better opportunities to certain learners according to their individual needs and, based on that knowledge, make better decisions regarding, for example, how to pair up or group students in order to meet specific goals, or how the kind of activities suggested in class may condition learners' positioning. In addition, knowledge regarding how positioning operates in the English classroom may facilitate teachers' own reflection on the ways they position different learners, and the rights they grant or deny to them, the discourses they draw on, and the impact that it all may have on both learners' identities and their use of English.

Finally, there is still a lot to be done in trying to explore processes of identity construction in Colombian language learners. One possible trend may be analyzing positioning in off-task class interactions such as learners' casual conversations with teachers and peers before or after lessons. These interactions could provide a deeper understanding on how learners and teachers negotiate power relations and positions in the classroom and the discourses that come into play in these situations. Moreover, processes of identity construction in the English classroom need to be explored more deeply in relation to issues of race, gender, ethnicity, class, among others, and see how they can determine specific dynamics of positioning through language. These type of research studies may shed light on how the micro system of power relations and positions in the English classroom may be linked to wider dynamics of positioning of larger groups, communities, and nations in order to contribute to the construction of more equitable relations among individuals and social groups. 


\section{References}

Andreouli, E. (2010). Identity, positioning and self-other relations. Papers on Social Representations, 19(1), 14.1-14.13.

Block, D. (2007). The rise of identity in SLA research, post Firth and Wagner (1997). The Modern language journal, 91, 863-876.

Canagarajah, S. (2004). Subversive identities, pedagogical safe houses, and critical learning. In B. N. Toohey (Ed.), Critical pedagogies and language learning (pp. 117-137). United States of America: Cambridge University Press.

Castañeda, H. (2008). “I Said it!" “I'm First!": Gender and language-learner identities. Colombian Applied Linguistics Journal(10), 112-125.

Davies, B., E Harré, R. (1990). Positioning: The discursive production of selves. Journal for the Theory of Social Behaviour, 20(1), 43-63.

Escobar, W., \& Gómez, J. (2010). Silenced fighters: Identity, language and thought of the Nasa people in bilingual contexts of Colombia. Profile, 12(2), 125140.

Foucault, M. (1982). The subject and power. Critical Inquiry 8(4), 777-795.

Foucault, M. (1998). The history of sexuality: The will to knowledge. London: Penguin.

Gómez, J. (2012). Language learners' identities in EFL settings: Resistance and power through discourse. Colombian Applied Linguistics Journal, 14(1), 6176.

Hall, S. (2000). Who needs 'identity'? In P. du Gay, J. Evans, \& P. Redman (Eds.), Identity: A reader (pp. 15-30). London: Sage Publications.

Hall, S. (2001). Foucault: Power, knowledge and discourse. In M. Wetherell, S. Taylor, \& S. Yates (Eds.), Discouse: Theory and practice (pp. 72-81). London: Sage.

Harré, D., \& Moghaddam, F. (2003). Introduction: The self and others in traditional psychology and in positioning theory. In D. Harré \& F. Moghaddam (Eds.), The self and others. Positioning individuals and groups in personal, political and cultural contexts (pp. 1-11). Westport, USA: Praeger Publishers.

Hawkins, M. (2005). Becoming a student: Identity work and academic literacies in early schooling. TESOL Quarterly, 39(1), 59-82.

Holland, D., \& Leander, K. (2004). Ethnographic studies of positioning and subjectivity: An introduction. Ethos, 32(2), 127-139.
Jiménez, R. (2000). Literacy and the identity development of Latina/o students. American Educational Research Journal, 37(4), 971-1000.

Kamberelis, G. E Dimitriadis, G. (2005). Focus groups: Strategic articulations of pedagogy, politics, and inquiry. In N. K. Denzin \& Y. S. Lincoln (Eds.), Handbook of qualitative research (3rd ed., pp. 887908). Thousand Oaks, CA: Sage

Macedo, D., Dendrinos, B., \& Gounari, P. (2003). The hegemony of English. Boulder Colorado, USA: Paradigm Publishers.

McKinney, C., \& Norton, B. (2008). Identity in language and literacy education. In B. Spolsky, \& F. M. Hult (Eds.), The handbook of educational linguistics (pp. 192-205). Singapore: Wiley-Blackwell.

Mejía, A. (2006). Bilingual education in Colombia: Towards a recognition of languages, cultures, and identities. Colombian Applied Linguistics Journal, (8), 152-168.

Ministerio de Educación de Educación Nacional. (n.d.). Plan Nacional de Bilinguismo. Retrieved from http:// www.mineducacion.gov.co/

Montenegro, A. (2012). Analyzing EFL university learners' positionings and participation structures in a collaborative learning environment. Colombian Applied Linguistics Journal, 14(1), 127-145.

Monzó, L., \& Rueda, R. (2009). Passing for English fluent: Latino immigrant children masking language proficiency. Anthropology \& Education Quarterly, 40(1), 20-40.

Morita, N. (2004). Negotiating participation and identity in second language academic communites. TESOL Quarterly, 38(4), 573-603.

Norton Peirce, B. (1995). Social identity, investment, and language learning. TESOL Quaterly, 29(1), 9-29.

Patton, M. Q. (1990). Qualitative evaluation and research methods ( $2^{\text {nd }}$ ed.). Newbury Park, CA: Sage.

Pavlenko, A., \& Norton, B. (2007). Imagined communities, identity, and English language learning. In J. Cummins, \& C. Davison (Eds.), International handbook of English language teaching (pp. 669680). New York, NY: Springer.

Richards, K. (2003). Qualitative inquiry in TESOL. New York: Palgrave.

Rojas, M. (2012). Female EFL teachers: Shifting and multiple gender and language-learner identities. Colombian Applied Linguistics Journal, 14(1), 92107.

Rondón, F. (2012). LGBT students' short range narratives and gender performance in the EFL classroom. 
Colombian Applied Linguistics Journal, 14(1), 7791.

Rymes, B., \& Pash, D. (2001). Questioning identity: The case of one second-language learner. Anthropology E Education Quarterly, 32(3), 276-300.

Warriner, D. S. (2007). Language learning and the politics of belonging: Sudanese women refugees becoming and being American. Anthropology \& Education Quarterly, 38(4), 343-359.

Watson-Gegeo, K. (2004). Mind, language, and epistemology: Toward a language socialization paradigm for SLA. TheModern Language Journal, 88, 331-350.

Wenger, E. (1998). Communities of practice: Learning, meaning, and identity. Learning in doing social, cognitive, and computational perspectives. Cambridge, United Kingdom: Cambridge University Press.

Wortham, S. (2004). The interdependence of social identification and learning. American Educational Research Journal, 41(3), 715-750. 